\title{
座屈・破断を考慮したブレース付骨組モデルと断層近傍強震動下の応答 BRACED FRAME MODEL CONSIDERING BUCKLING AND FRACTURE AND ITS RESPONSES UNDER NEAR-FAULT STRONG MOTIONS
}

\author{
金尾伊 織*, 中島正愛**, 竹 原 創 平*** \\ Iori $\cdot$ KANAO, Masayoshi NAKASHIMA and Sohei TAKEHARA
}

\begin{abstract}
This paper presents an analytical model for the simulation of steel braced frames in which both buckling and fracture of the braces are considered. The cross-section consists of many fiber segments, with each element taken to lose its resistance at the time of fracture. A sudden loss of resistance is converted to an immediate inertial force to maintain the overall equilibrium. The proposed model is applied to a three-story braced frame whose earthquake response behavior is examined for multiple near-fault ground motions. The effect of buckling on the maximum story drift is most notable with significant increases in the maximum story drift. The effect of brace fracture is found secondary particularly when the fracture occurs after buckling.
\end{abstract}

Keywords: brace, near-fault earthquake, buckling, fracture, fiber segment, spatial large deflection analysis

ブレース, 断層近傍強震動, 座屈, 破断, 一軸材料線要素, 立体大たわみ解析

\section{1.はじめに}

1994 年米国ノースリッジ地震, 1995 年兵庫県南部地震, 1999 年台湾集集地震ら近年の大地震は, 建築構造物に大きな被害をも たらした ${ }^{1}$ 。築後何十年も経た建物, あるいは, 耐震性能が現行 の耐震設計において要求されるレベルに達していない建物の被害 が多数を占めていたが, その一方で, 破壊断層近傍で記録された 強震動は, 現行耐震設計が想定する大地震時の地震動を遙かに超 すものであった ${ }^{2), 3)}$ ，このような強震動に対しては, 現行耐震設計 が要求する耐震性能を保有する建物においても，損傷を免れえな い事態が発生する可能性がある。このような状況において, 建築 構造物が自重保持能力を消失し完全に崩壊するまでの保有性能を 定量化することは, 既存建物に対してはより合理的な保有耐震性 能の評価, 新規建物に対しては耐震設計想定以上の過大地震時に おける余裕度の把握，という観点からもたいへん重要である。

建築構造物が完全に崩壊するまでの挙動を追跡するためには, 構造物を構成する部材の座届, 破断などの不安定要因を取り込ん だ解析が必要となる．現在までに，応用要素法を用いた RC 構造 物の完全崩買解析 ${ }^{4)}$, 鋼構造柱の連鎖破断を考慮した骨組動的解 析 ${ }^{5}$, 鋼構造梁の破断を考えた骨組静的・動的解析 ${ }^{6 \sim 8)}$, 履歴ダン パーの破断を考えた骨組動的解析 ${ }^{9}$ などが発表されている。しか
しながら，破断に付随する突然の応力状態変化やトポロジー変化 を精度よく追跡することは難しく，現在に至るまで，座届や破断 を考虑しつつ構造物が完全に崩壊するまでの挙動を追跡した例は 限られている。

これらの事情を踏まえ，本論では，鋼構造ブレース付骨組を対 象にし，その主要水平抵抗要素であるブレースが地震応答特有の 絽返し変形下において座届し，さらに亀裂が発生・進展してつい には完全に破断するまでの挙動を追跡できる解析法を提案する. さらにこの解析法を用いて，3 首ブレース付骨組の地震応答を, 地 震動の種類, 座屈の有無, 破断の有無を変数とした一連の解析か ら検討し, これらの変数がブレース付骨組の地霞応答に及ぼす影 響を明らかにする。

\section{2. 破断を考慮した動的解析法}

\section{1 解析法の概要}

強地震動を受けるブレース付骨組において，ブレースの座届・ 破断は，その応答特性に大きく影響を与える可能性がある。しか し，構造物の部材が破断する場合，破断直前まで存在していた応 力が瞬間的に消失するので, 静的な力の釣合に頼る静的解析では, 破断を含む応答の追跡は難しい.

\footnotetext{
* 京都大学大学院工学研究科建築学専攻 助手・博士 (学術)

** 京都大学防災研究所地震災害研究部門 教授・Ph. D 
一方，第一著者らは，強非線形挙動を精度良く追跡することを 意図した梁 - 柱有限要素法による静的解析法を提案し，この解析 法の精度を検証するために, 繰返し曲けをを受ける $\mathrm{H}$ 形鋼梁の横座 届実験，小型立体鍓ラーメン実験を模擬し，十分な精度を有して いることを確認してきた ${ }^{10), 11)}$ 。この解析法は，一軸の構成則に従 う材料線要素を導入するとともに，三次元大変形を精度良く測る ために，有限回転を考慮した座標変換則および移動座標系を採用 している.さらに，この解析法を動的解析に挔張し ${ }^{12)}$ ，小型銅骨 組の振動台実験を対象とした解析を行い，この動的解析法が精度 良く動的実験を模擬できることを検証している. 本論では, この 動的解析法に破断モテルを導入し, 部材の破断を考慮した骨組解 析法を提案する.

\section{1 １ 1 運動方程式の誘導}

運動方程式に用いる質量行列, 減衰行列, 剛性行列の概要を以 下に示す.なお, 解析法の詳細については文献 10)〜 12) を参照 されたい.

柱一梁部材の自重, 等分布荷重は整合質量行列 12)を用いて表し, 節点位置に集中質量がある場合は，集中質量を用いる。いずれの 質量も，全体座標系の節点位置に附加される，減衰行列は, 質量 行列と岡性行列に比例するレーリー減衰を採用し, 1 次, 2 次とも 減衰定数 $2 \%$ としている.

系剛性行列は，すでにその精度を検証した梁 - 柱有限要素法か ら得られる剛性行列を採用している.この剛性行列は, 大変形時 の有限回転を考慮した座標変換則により定式化している．部材は 一様な断面を持つ直線部材であり，材軸方向に直列に並ぶ片持ち 梁 - 柱要素からなる.いくつかの要素に分割された部材は伝達行 列の手法を用いて部材両端の節点情報に集約される. 各要素は図 1 に示すように, いくつかの材料線要素で構成され, 断面諸量は, 材料線要素に割り当てる集中断面積 $A_{i}$ と図心軸を基準としたその 線要素の位固 $\left(x_{i}, y_{i}\right)$ から計算される. 集中断面積と図心軸からそ の要素までの距離は, 元の断面の断面積 $A$, 塑性断面係数 $Z_{p x}, Z_{p y}$, 断面二次モ -メント $I_{x}, I_{y}$, 反り二次モ - メント $I_{w}$, サンブナンの ねじれ定数 $K$ が一致するように決定する，以下，部材を構成する 要素を要素, 要素を構成する一軸材料線要素を線要素と呼ぶ.

\section{1 . 2 破断モテル}

破断によって瞬間的に発生する不釣合力については，その力を 打ち消す慣性力を与えて不釣合力を処理する手法が一般的に用い られる4) 6). 本解析法においてもこの方法を用いて, 破断が発生 した次ステップにおいて，不釣合力を破断した要素の両節点に存 在する質点の慣性力として処理する.

図1(a)のように, 部材を楧成する要素が変形すると，その要素を 構成する各線要素は変形に応じて軸引張, 圧縮を受けるが, 引張を 受ける線要素のひずみがあるひずみ（破断ひずみ $\varepsilon_{f r a c}$ ）に達した時, その線要素が抵抗力を失うとして破断を考慮する. 抵抗力を失った （破断の）瞬間に発生する不釣合力については，その力を打ち消す 慣性力を与えて不釣合力を処理する手法が一般的に用いられる，本 解析法においてもこの方法を用いて，破断が発生した次ステップに おいて, 不釣合力を破断した要素の両節点に存在する質点の慣性力



(a) Deformation

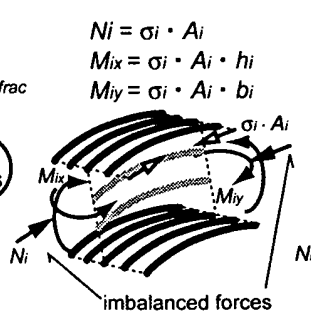

(b) Imbalanced force

Fig. 1 Fracture model

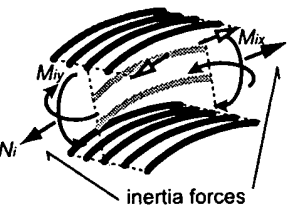

(c) Inertia force

として処理する．具体的には，破断した線要素は消失し，部材要素 断面は破断していない他の線要素から構成されるものとして，断面 積, 断面二次モーメントなどの断面諸量を変更し, 剛性行列を修正 する. なお，破断後も断面保持の仮定が成立するものとしている. 一方，不釣合力は以下の手順で処理する．破断時に，破断線要素に 生じている引張力とその線要素の位置から，材軸における不釣合力 を算定する. 図 1(b)に示すように, 部材要素内の 1 線要素が破断し た場合，その線要素に発生している応力 $\sigma_{i}$ と集中断面積 $A_{i}$ から計算 される軸力 $N_{i}, N_{i}$ と線要素の位置 $h_{i}, b_{i}$ から計算される曲げモーメ ント $M_{i x}, M_{i y}$ が, 破断要素の両節点に不釣合い力 $N_{i}, M_{i x}, M_{i y}$ とし て発生する. 破断発生の次ステップで, 不釣合力 $N_{i}, M_{i x}, M_{i y}$ を打 ち消すため, 同じ大きさで逆向きの慣性力を破断線要素を有する要 素の両節点の質点に附加する（図 1(c)).

以上の手順に従って求めた増分型運動方程式を，平均加速度法に よって解く. また, 材料線要素の降伏, 除荷, 破断の判定は, 各線 要素の中央ひずみを参照する．線要素の降伏 (破断)の判定は, 線要 素のひずみが目標とするひずみの土 $0.1 \%$ の範囲を降伏(破断)とし， その範囲をひずみが飛び越す場合, 時間幅を小さくして再計算し， 降伏 (破断) 点がこの範囲に収まるようにしている.なお, 破断後も 質量, 减衰行列は変化しないものとし, 破断面接触による耐力の再 上昇は考虑していない，また，破断は，過去の履歴にかかわらず引 張ひずみが指定した限界值に達すれば生じると仮定する. 以下, 同 じ手順を繰り返し, 部材の一部が破断する状況や, 部材が完全に破 断する状況を含めて, 線要素が順次破断してゆく過程を追跡する.

\section{2 解析例}

図 2 に示す 1 層 4 スパンのブレース付骨組を対象とし, 破断を 考虑しないモデ，破断を考慮したモデルの地震応答解析を行っ た. 以下, 部材の一部が破断することを破断, 部材が完全にちぎ られることを完全破断と呼ぶ.

部材断面はそれぞれ図 2(a)に示すとおりであり，柱は水平力に 対して弱軸, ブレースは構面内に座屈するように配直している. 柱は 8 要素, 梁, ブレースは 10 要素に等分割している. 図 2(a) 中 ○で示した柱頭部とブレース内 5 所に節点を設け, 質量はその 節点位直に附加している. また, 図中○で示したブレースの両端 と中央部を破断可能点に指定する. 応力ひずみ関係には, 図 2(b) に示すバイリニア移動硬化型モデルを採用しており, 降伏応力は $235 \mathrm{MPa}$, ヤング係数は $205 \mathrm{GPa}$, 降伏後の係数は $0.82 \mathrm{GPa}$ であ る. 降伏後の係数は， $20 \%$ のひずみが生じた時に応力が概ね $400 \mathrm{MPa}$ となる勾配である. また, 破断を考慮した解析では, 引 張ひずみが $2 \%$ に至った場合に破断すると仮定する．図2(c)は柱， 

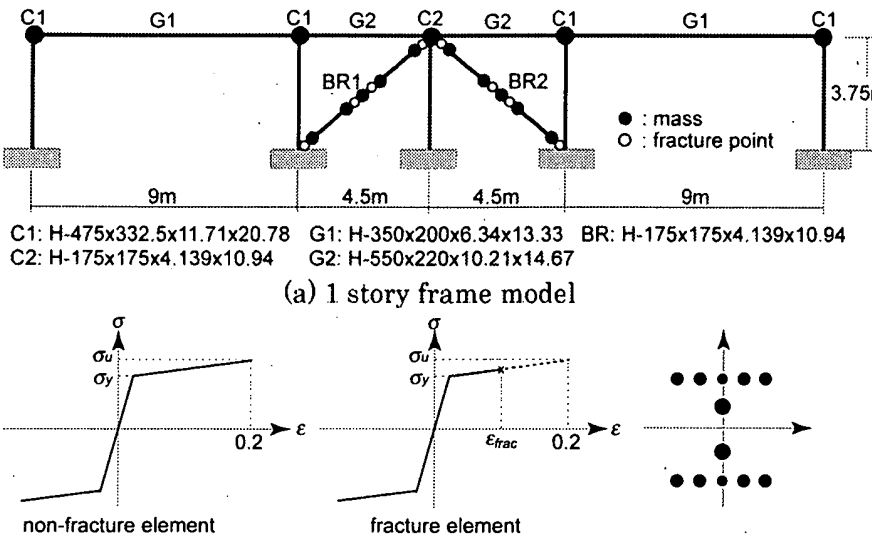

(b) Stress-strain relationship

(c) Cross-section model

Acceleration $\left(\mathrm{m} / \mathrm{s}^{2}\right)$

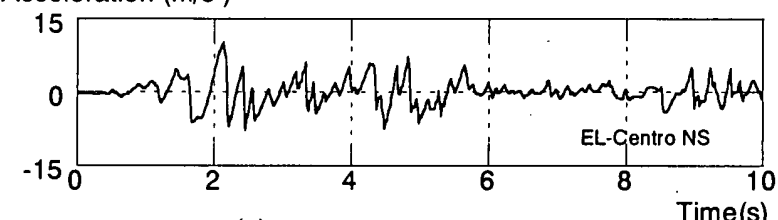

(d) Ground acceleration

Time(s)

Fig.2 Analysis model

梁, ブレースに用いる H 形断面のモデル化で, 12 材料線要素で構 成されている.なお, ここでは平面問題を対象とし, 面外変形を 防ぐために，構面外の並進変位と回転角を拘束している.

対象とした骨組の固有周期は 0.17 秒, ベースシア係数は降伏時 1.40, 終局時 0.88 , ブレースの水平力分担率は弹性時 0.91 , 終局 時 0.75 である. ブレースの細長比は 125 , ブレースの降伏耐力は $804 \mathrm{kN}$ であり，ブレース両端部は剛接合としている. EL-Centro $\mathrm{NS}(1940)$ の最大速度を $1.0 \mathrm{~m} / \mathrm{s}$ に挔幅した波を入力し, 10 秒間 解析した. 入力最大加速度は $10.2 \mathrm{~m} / \mathrm{s}^{2}$ である.

図 3 に解析結果を示す. 図 3(a) は層間変形角時刻歴を示し, 太 線は破断を考慮しないモデル，細線は破断を考慮したモデ， $\times$ は部材の一部が破断した位置を示している. 図中に示している.H 形断面の図は破断した要素における断面の最終状態を示し， メは 破断した線要素，○は破断せずに残った線要素を示す．左側ブ レース (BR1) はブレースの中央部が破断し, 右側ブレース (BR2) はブレースの柱脚との接合部が破断している.

破断を考慮しないモデルは, $1.8 \mathrm{sec}$ から徐々にブレース BR1が 座屈し始め, $2.3 \mathrm{sec}$ 時に BR1 の座屈後変形が急激に進行し, 層 間変形角が $0.0063 \mathrm{rad}$ に至った．続いて逆方向の入力によって BR2 が座届し，最終的には，骨組全体はBR2 が座屈した方向に 偏って変形している，一方，破断を考慮したモデルは，最大層間 変形角を示した後にBR1の部材中央の断面を構成する線要素が順 次破断し, 最終的には断面の半分以上が破断している. また, BR2 はフランジの一部が破断した状態に留まり，いずれのブレースも 完全破断に至っていないものの，BR2 破断直後から周期が顕著に のび, 変形も增大する傾向を示している.

図 3(b) は座屈を考慮し, 破断を考慮しない場合の層せん断力と 層間変形角の関係を示す，座屈によって，耐力がおよそ半分まで 低下している.一方, 図 3(c) は座屈と破断を考慮したモテルの層 せん断力と層間変形角の関係であり，図中×は破断点を示す．ブ レースが破断するたびに剛性，層せん断力が低下し，最終的には

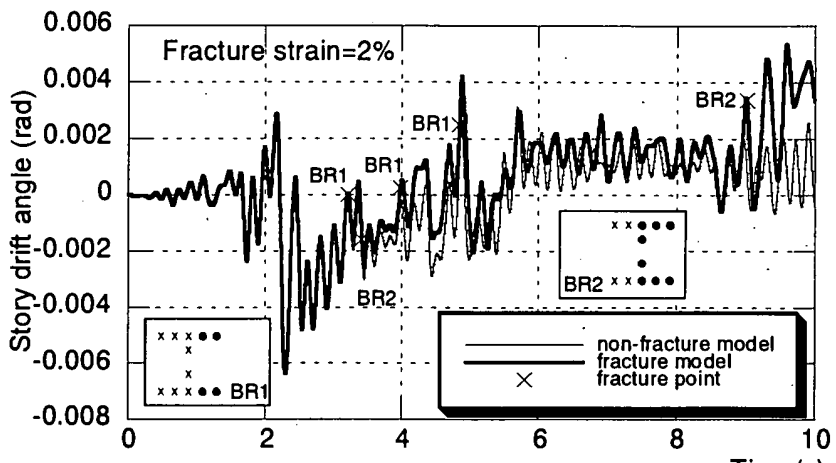

(a) Time history of story drift angle

Time(s)

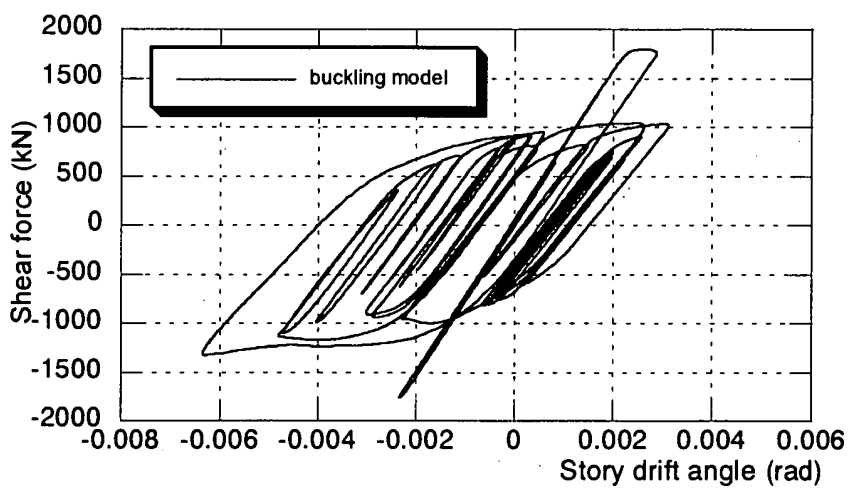

(b) Non fracture model



(c) Fracture model

Fig. 3 1story braced frame

破断によって最大耐力の $35 \%$ まで低下している.

図 3(c) では判別できないが, 上谷ら ${ }^{6}$ が指摘しているように, 破 断直後に高周波回転振動が発生するとともに復元力が低下し, さら にこの振動が短時間内に減衰するという現象が見られている。

\section{3.フレース付骨組の地震時挙動特性}

前節に示した解析法を用いて, 地震力を受けるブレース付骨組 の応答特性を, 特に, ブレースの座届・破断に着目して考察する.

図 4 に示す 3 層 4 スパンのブレース付骨組を対象とした. 部材 断面は図 4(a) に示す通りである，対象とした構造物は文献 13)， 14）に記された設計概要に準じており，一般的な仕上げ, 載荷重 量に基づき，現行の設計基準に従うて設計された骨組である。柱 梁は A ランク, 1 階筋違は $\mathrm{BB}$ ランク， 2,3 階は BC ランクであ り，構造特性係数は 1 階は $D_{s}=0.3 ， 2,3$ 階は $D_{s}=0.4$ である. 柱 は水平力に対して弱軸，ブレースは構面内座屈が考慮できるよう に配置し, 接合部は剛接合としている. 柱は 4 要素, 梁, ブレー 


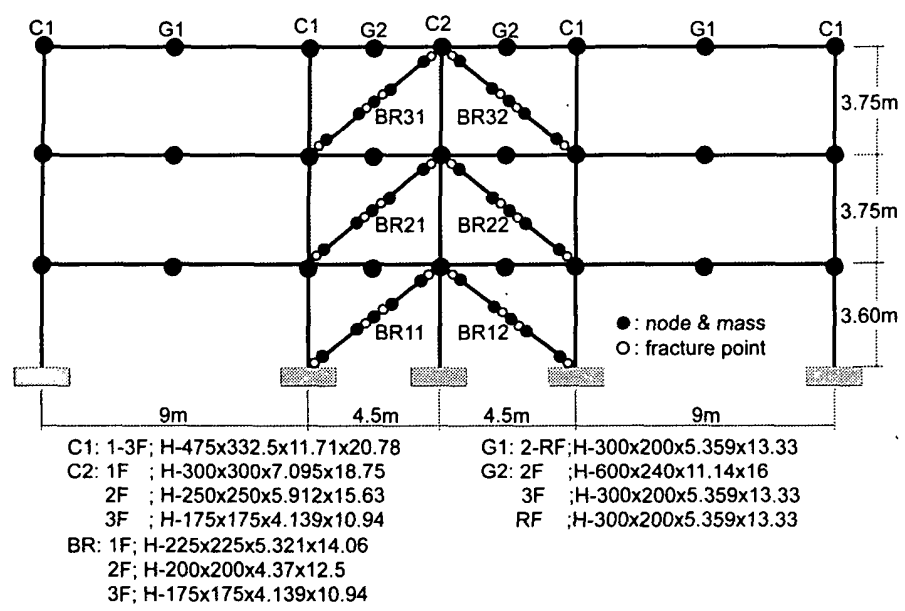

(a) 3-story frame model


Fig. 4 Analisys model

スは 10 要素に等分割している. 図 4(a) 中○は節点, ○はブレー スの破断可能点を示す。質量は節点に附加され，質量の与え方は 文献 13)，14）を参考にしている，応力ひずみ関係には，先と同様 にバイリニア移動硬化型モデルを採用しており，降伏応力は $325 \mathrm{MPa}$ ，ヤング係数は $205 \mathrm{GPa}$ ，降伏後の係数は $0.82 \mathrm{GPa}$ であ る.また, 面外変形を拘束した平面解析を対象としており, 他の 解析条件等は先の解析例に準じている.

対象とした骨組の固有周期は 0.46 秒, ブレースの弱軸回りの細 長比は 1 階 95,2 階 110,3 階 125 , 水平力分担率は弾性時で 1 階 $0.94,2$ 階 $0.92,3$ 階 0.91 , 終局時で 1 階 $0.77,2$ 階 $0.63,3$ 階 0.54 である. また, 層せん断力係数は弾性時で 1 層が $0.62,2$ 層が 0.53 , 3 首が 0.49 , 終局時で 1 層が $0.52,2$ 層が $0.44,3$ 首が 0.45 である.

ここで対象とした入力地震波は, 破壊断層近傍で記録された, 継続時間は比較的短いが大きな速度パルス波で特徽づけられる強 震動で, ノースリッジ地震 (1994), 兵庫県南部地震 (1995), 台湾 集集地震（1997）において得られた断層直交方向地震動記録波から 1 つずつ選んだ（図 4(b)). 以下，それぞれNF13，JMA Kobe,
TCU084 と呼ぶ．ここで選択した強震動はいずれも，0.5 秒程度 の弾性固有周期を有する建物の変形が特に降伏後に增大すると予 測されるもので，最も摇れが大きい 10 秒間を解析に用いた．また 比較のために，建策骨組の耐震設計において頻繁に用いられる最 大速度を $0.5 \mathrm{~m} / \mathrm{s}$ に基準化した EL-Centro(1940) 波の NS 成分（以 下 El-Centro）も解析対象地震波とした. 各地震動の最大速度お よび最大加速度は, JMA Kobe が $0.89 \mathrm{~m} / \mathrm{s}, 8.10 \mathrm{~m} / \mathrm{s}^{2}$, NF 13 が $1.74 \mathrm{~m} / \mathrm{s}, 8.73 \mathrm{~m} / \mathrm{s}^{2}$, TCU084が $1.17 \mathrm{~m} / \mathrm{s}, 9.89 \mathrm{~m} / \mathrm{s}^{2}$, EL-Centro が $0.5 \mathrm{~m} / \mathrm{s}, 5.11 \mathrm{~m} / \mathrm{s}^{2}$ である.

以下に示す解析結果は, 最大層間変形角を示す図では, 縦軸は 階首, 横軸はブレースが取り付くスパン中央の柱 $\mathrm{C} 2$ の各層最大 層間変形角を示し, 実線は TCU084, 点線は NF13, 一点鎖線は JMA Kobe, 破線は EL-Centroの結果を示す. また, 復元力特性 を示す図では, 縦軸はブレース 1 組のせん断力, または, ブレー スを除いたラーメン骨組が負担するせん断力, 横軸は柱 C2 の層 間変形角を示す。

\section{1 プレース付骨組の挙動特性 \\ 3.1.1 プレース付骨組}

破断を伴う解析の前に, 破断を考慮しないブレース付骨組の地 震応答解析を行った結果を図 5 に示す. 図 5(a) は各層の最大層間 変形角である. JMA Kobe や EL-Centroのような最大加速度が 相対的に小さい地震動では，2層目のブレースが座届し， 2 層目の 変形が最大となる層崩壊の様子を呈しているが, TCU084 や NF13 のような最大加速度が非常に大きい地震動では, 他層のブ レースもほほ同時に座屈しており，2 層以外の首も大きく変形し， $0.1 \mathrm{rad}$ を超える最大層間変形角に達している場合もある，一方， EL-Centroは最大でも0.013rad 程度の変形角に留まっており， 断首近傍強震動（特にNF1.3，TCU084）が耐震設計で通常想定さ れてきた地震動より相当大きな変形を与えることがわかる．図 5(b)，(c)に，TCU084の地震動を受けたときの 2 層目ブレースの 復元カとブレース以外の骨組の復元力を示す．図 5(b) は，比較的 短いブレース特有の性状を示している15).ブレースが座屈するこ とで耐力は半分以下にまで低下しており，座屈がブレース付骨組 の耐力, 剛性低下を支配することがわかる. 一方, 骨組はブレー スの座屈に関わらず, $1000 \mathrm{kN}$ 程度のせん断耐力を有し，これは 骨組全体が有する最大復元力の $25 \%$ 程度にあたる.

\section{1 ．２座屈を拘束したブレース付骨組}

ブレースの座屈が耐力劣化と変形の增大を引き起こすことを踏ま え，座屈拘束の効果を考えることとし，先のブレースと断面積は 同じであるが座届しないブレース付骨組を解析する.ブレースの 座屈を拘束するために, ブレースの曲け剛性を 10000 倍してい る.ここでも部材の破断は考慮しない。

図 6(a) は各層の最大層間変形角を示す．座屈を拘束することに よって, JMA Kobe では 2 層目に変形が集中する層崩壊も抑えら れ，いずれの地震動に対しても変形は，最大層間変形角が座届す る場合の約半分に抑えられている．図 6(b)，(c)に示すTCU084 に対する復元力特性は，安定した履歷を描いており，層間变形角 が $0.05 \mathrm{rad}$ においても, ブレースが水平力の $80 \%$ を負担している. 


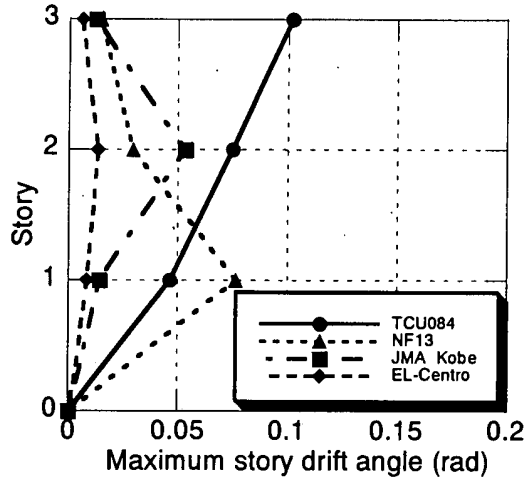

(a) Story drift angle of braced frames



(a) Story drift angle of braced frames



(b) Restoring force of brace (TCU084)

Fig.5 Braced frames involving buckling

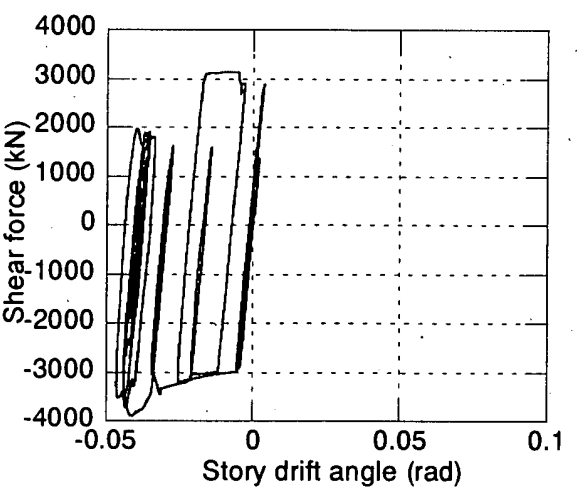

(b) Restoring force of brace (TCU084)

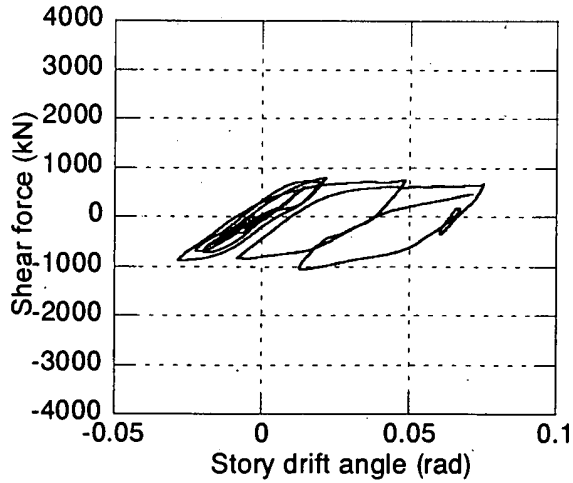

(c) Restoring force of frame (TCU084)

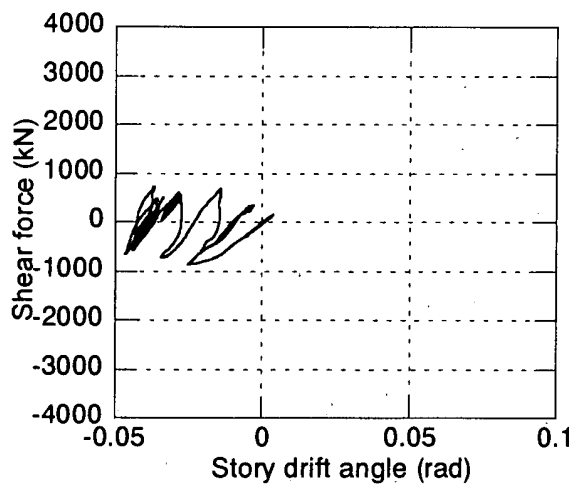

(c) Restoring force of frame (TCU084)

Fig.6 Frames with buckling restrained braces

\section{2 ブレース付骨組の破断挙動特性}

\subsection{1 プレース付骨組}

ブレースが破断する場合の挙動を考察する．先の解析と同じ応 カひずみ関係とするが, ブレース断面を構成する線要素の引張ひ ずみが $6 \%$ に達したときに, ブレースの両端部と中央部が破断す ると仮定する．その他の解析条件は前節に準じている.

図 7 に解析結果を示す. 各層の最大層間変形角を示す図7(a)を 破断を考慮しない骨組の結果（図 5(a)）と比較すると；いずれの 地震動に対しても，破断の有無に関わらず最大変形はさほど変わ らず，地震動によっては，破断によってむしろ最大層間変形角が 低減しているものもある.このように最大変形の違いが少ないの は，ブレースが座屈した後に破断しているからである。図 7(b)， (c)にTCU084の地震動を受けたときの復元力を示す．図中×は ブレース破断発生点である。この骨組は，ブレースが完全破断に は至らず，各階のブレース端部が部分的に破断している. 図 5(b) では座屈によって耐力が最大耐力の $30 \%$ まで低下していたことを 考慮すると，座届後の破断による耐力低下は数％にとどまり，座 屈による影響よりはるかに小さい．このように，座屈後の部材の 破断は最大層間変形角にほとんど影響を与えていない。

\subsection{2 座屈を拘束したブレース付骨組}

3. 1 . 2 に述べた座屈拘束したブレース付骨組を対象に，ブ レース破断の影響を解析する．破断ひずみを $0.6 \%$ とし，その他 の解析条件は前節に準じている.

図 8(a)に各層の最大層間変形角を示す，破断を考慮しない座屈 拘束された骨組の結果（図 6(a)）と比較すると, TCU084 を除い
て最大層間変形角は $20 \%$ から $50 \%$ 程度增加しているが, 破断を 考慮せず座屈拘束もしない骨組（図 5(a)）に比べれば，最大層間 変形角は相当小さい. 図 8(b), (c) にTCU084の地震動を受けた ときの 2 層目の復元力特性を示す．完全破断に至ったのは， 1 層 目左側ブレース BR11 の端部と 2 層目右側ブレース BR22 の中央 部のみであり，他のブレースに破断は見られない，図 5(b)，(c) と 図 8(b)，(c) を比較すると, 破断よりもむしろ座屈による耐力低下 と変形の增加が著しい。

TCU084では破断を考慮する之最大変形が顕著に低減したが, その理由として, 塑性化, 破断による固有周期の変化が考えられ る. TCU084の応答スペクトルによれば, TCU084 は周期 0.9s で 最大応答を呈し，それ以上の周期では応答が減少する傾向にある. ここで対象とした骨組において 2 層目ブレースが破断した場合の 固有周期は $1.02 \mathrm{~s}$ であり, 破断後の固有周期の伸びが応答减少に 寄与した可能性は高い。

\section{4 結語}

一軸材料線要素からなる梁一柱有限要素を用いた動的解析法に 破断モデルを導入し，ブレース破断を考虑したブレース付骨組の. 地震応答解析を行った。主な知見は以下の通りである。

(1) 要素を構成する一軸材料線要素のひずみが, 破断ひずみに達 した場合，その 1 材料線要素のみが消失したものとして，消失さ れる内力を次ステップの慣性力として考慮する破断モデルを提案 した．このモデルによって，完全破断を含む部材破断を考慮でき ることを示した．

（2）断層近傍強震動は，建築耐震設計において通常想定されてき 




(a) Story drift angle of fracture frame model

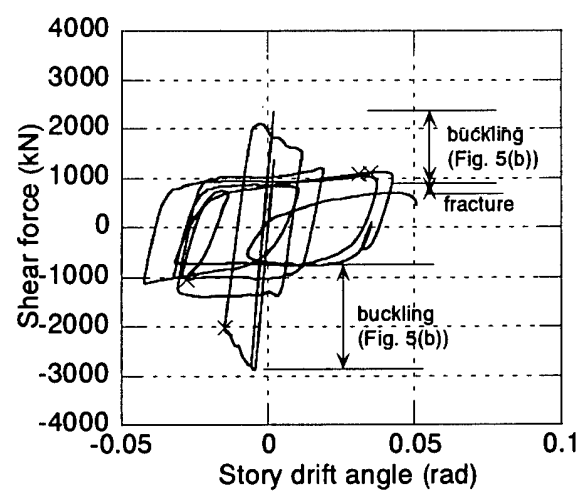

(b) Restoring force of brace (TCU084)



(c) Restoring force of frame (TCU084)

Fig.7 Braced frames involving buckling and fracture



(a) Story drift angle of fracture frame model



(b) Restoring force of brace (TCU084)

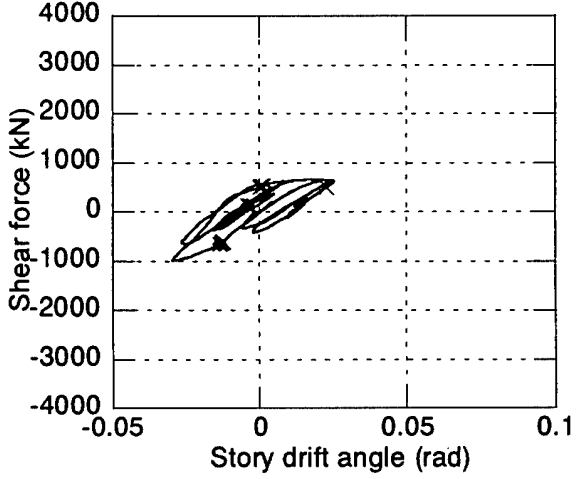

(c) Restoring force of frame (TCU084)

Fig.8 Frames with buckling restrained braces involving fracture

た地震動より相当大きな変形をブレース付骨組に与えうる.

（3）ブレース付骨組は，ブレースの座屈後の耐力劣化が大きな層 間変形角を引き起こす．ブレース座屈を拘束することは，骨組の 最大層間変形を減少させ, 安定した挙動を保持するために極めて 有効である.

（4）本解析で用いたブレース付骨組（ブレース細長比 $=95 \sim 125 ）$ では，座屈の方が破断よりも骨組の最大層間変形に及ぼす影響が 大きく, とりわけ座屈後の破断は最大層間変形にほとんど影響し ない.

本論では，ブレースの破断を，ブレース断面を構成する線要素 がある限界ひずみに至ったときに突然抵抗力を失うとの仮定に よって表現し，また限界ひずみを，ひずみ履歴に依存しないある 一定の引張ひずみに指定した．限界ひずみの大きさやひずみ履歴 がブレースの破断やブレース付骨組の応答特性に及ぼす影響につ いては, 後続論文で詳細に報告したい.

\section{謝辞}

京都工芸瀻維大学 森迫清貴教授，同大学院生 門藤芳樹氏に は，梁一柱有限要素を用いた動的解析法を提供していただきここ 協力, ご助言を賜りました。東京大学生産研究所目黒公郎助教 授，同大学院生 Paola Mayorca 氏には，破断解析に関して多く のご助言を賜りました。 大阪大学 多田元英助教授には，本解析 構造物に関する資料を提供していただきました。ここに，哚く感 謝の意を表します。

\section{参考文献}

1）例えば，日本建築学会:阪神・淡路大震災調查報告，1997.10.

2）松宮智宏，中島正愛，浅野幸一郎:断層近傍強祳動を受ける銅構造骨組の地震
応答とモーダル分解による評価，第 11 回日本地霞工学シンポジウム， 257 , 2002.11.

3) Akshay Gupta and Helmut Krawinkler: Behavior of Ductile SMRFs at Various Seismic Hazard Levels, Journal of Structural Engineering, Vol.126, No.1, pp.98·107, 2000.

4) Hatem Tagel-Din and Kimiro Meguro:Applied Element Simulation for Collapse Analysis of Structures, Bulletin of Earthquake Resistant Structure Research Center, No. 32, pp.113·123, 1999.

5）桑村仁，传藤義也：強震を受ける柱降伏型多首骨組の脆性連鎖崩壊，日本建築 学会楧造系論文集, 第 483 号, pp.61·70, 1996.5.

6) 上谷宏二, 田川浩:部材破断を伴亏銅構造骨組の動的応答解析法, 第2回日本 計算工学請演会論文集, pp.947·950, 1997.

7）日下彰宏, 中島正愛,野中泰二郎:梁部材破断を考虑した鉄骨平面骨組の挙動 と信頼性評価, 日本建築学会構造系論文集, 第 493 号, pp.99-106, 1997.3.

8) Masayoshi Nakashima, Takeshi Minami and Isao Mitani:Moment Redistribution Caused by Beam Fracture in Steel Moment Frames, Journal of Structural Engineering, Vol.126, No.1, pp.137-144, 2000.

9）田川浩, 上谷宏二, 吉谷聡志: 履歴型ダンパーの破断を伴う鎆構造骨組の地震 応答，鋼構造論文集，第 5 巻第 20 号 pp.17·25, 1998 .

10) 金尾 (奥田) 伊織, 森迫清貴, 中村武:一軸材料線要素からなる梁-柱有限要素 を用いた銅立体ラーメンの弹塑性举動の解析, 日本建築学会構造系諭文集, 第 533 号, pp.99・106, 2000.7.

11) 金尾伊織, 中島正愛,劉大偉: 綝り返し載荷を受けるH形鋼梁の横座座挙動と 横座属補剛，日本建筑学会構造系論文集，第 544 号, pp.147-154，2001.6.

12) 門藤学樹, 金尾伊織, 森迫清貴: 梁-柱有限要素法による立体弾望性骨組の動 的大たわみ解析, 日本建築学会構造系論文集, 第572号, pp.105-110, 2003.10 .

13) 川北悠介, 多田元英, 福井智則, 中島正愛:日米の各規準で設計された筋かい 付ラーメン構造のベースシアー耐力比較（その1 規淮式に基づく比較), 日本


則, 多田元英, 川北悠介, 中島正受:日米の各規準で設計された筋かい付ラー メン構造のベースシアー耐力比較(その2 試設計結果による検討), 日本建築 学会大会学術講演梗概集 (北陸) 構造 III, pp.917·pp.918, 2002.

14）多田元英:銅構造建築の耐震設計規準に関する日米比較と両基準に基づく設計 例, 2002年度第2回研究会資料, 日本建勧学会近幾支部鉄骨構造部会, 2002.12.

15）若林賽 編著:鉄骨構造学詳論，丸善株式会社, 1985 